\title{
A KORRUPCIÓ ÉS A VÉDEKEZÉS LEHETŐSÉGEI
}

A Magyar Tudományos Akadémia Ipari és Vállalatgazdasági Bizottsága 2009. október 9-én rendezte harmadik korrupcióellenes konferenciáját. Az előadók, a magyar közélet 14 prominens személyisége, közül ketten a politikai élet ismert szereplői, további ketten a magyar jog és igazságszolgáltatás vezetó tisztségviselói voltak. Hatan közvetlenül a korrupció által leginkább sújtott területek elöljáróiként, hárman kutatóként (jeles egyetemi tanárként), s egy kamarai vezetố a vállalati szféra képviseletében fejtette ki nézeteit a témáról. Amint ezt dr. Papanek Gábor, a Bizottság és a konferencia elnöke kiemelte, a rendezvény, a sok, olykor egymást kiegészítő, olykor ütközố nézet törekedett világos áttekintést adni a korrupció okairól, hatásairól, valamint az e visszaélés elleni küzdelem aktuális tennivalóiról.

Dr. Avarkeszi Dezsố, az Igazságügyi és Rendészeti Minisztérium (IRM) államtitkára, a rendezvény fő előadója a Minisztérium, illetve a kormányzat korrupció ellenes stratégiájával kapcsolatosan mindenekelőtt azt emelte ki: arra törekszenek, hogy ,a kormányzati korrupcióellenes politika tudatosabbá tételével, valamint a szükséges feltételek megteremtésével a nemzetgazdaságon belül csökkenjen a korrupciós piac részesedése, és, hogy a láthatatlan folyamatok mindinkább láthatóvá váljanak". Célkitüzésük legfő́bb indokát abban látják, hogy „,a korrupció államigazgatási múködési kockázatként jelentkezik, komoly versenyképességi tényezơ". Első lépésként 2007-ben sor került az Antikorrupciós Koordinációs Testület felállítására, melynek tagjai különböző kormányszervek $^{1}$, egyéb, nem kormányzati állami szervek képviselői, valamint az elnök által részvételre felkért tagok - civil szervezetek képviselói ${ }^{2}$ és a téma szakértői ${ }^{3}$.

Jelenleg is van együttmúködés a hazai állami szervek, illetve a korrupció elleni küzdelem mellett elkötelezett fejlett államok képviseletei között. Rendszeres kapcsolatok épültek ki a G8 államok nagyköveteinek kezdeményezésére létrejött Transparency Working Grouppal. A korrupció elleni küzdelemben alkalmazható hazai eszköztár fejlesztése érdekében az elmúlt félévben „,intézményesült” tudásátadásra került sor holland és magyar szakemberek között. Az eddig példa nélküli szakmai együttmúködés következtében mindössze néhány hónap alatt, 2008 elejére elkészült egy szakmai javaslat a korrupció elleni fellépés hosszabb távon is érvényes lehetséges céljairól, prioritásairól, valamint a már rövid távon is teljesítendó feladatokról (Stratégia és Cselekvési Program).

A Korrupcióellenes Stratégia deklarált célja, hogy „egyidejúleg és azonos mértékben törekszik a korrupciós helyzetek megelôzésére, valamint a már feltárt korrupciós cselekmények érintettjeinek felelősségre vonására.”. Ennek érdekében egyaránt szükséges a különbözó korrupciógyanús esetek felderítése, a prevenció, a felelősségre vonás, s a különböző korrupciós okok felszámolása. De nem elkerülhetô a különböző szabályozási problémák kezelése, kockázatelemzés, az ellenőrzésbeli hiányosságok korrekciója, az átláthatósági és gondolkodásbeli problémák kezelése, az antikorrupciós jelzőrendszer fejlesztése, vagy a szankciórendszer átalakítása sem.

Mindezek alapján a minisztérium négy különösen problémás területet jelölt meg, ezek a párt- és kampányfinanszírozás és annak rendezése, a fejlesztési támogatások tiszta és átlátható felhasználása, a közbeszerzési eljárások átláthatóságának javítása, valamint a korrupció visszaszorítása a hatósági engedélyezési gyakorlatban. Itt a Minisztérium az Antikorrupciós Stratégiához csatlakozó rövid távú Cselekvési Programot is kialakított. Az elmúlt évek legfontosabb, a Cselekvési Programban megfogalmazottakkal összhangban álló kormányzati intézkedései a közbeszerzési eljárások módosításai, a támogatási rendszerek átláthatóságának javítása, illetve a pártfinanszírozás kérdésének rendezése. 
Dr. Szikora János, az APEH elnöke az APEH korrupció elleni tennivalóinak komplex megközelítését szorgalmazta a jelenlegi „bünbakkeresés” helyet. Emlékeztetett rá, hogy az OECD 1996-os korrupció kézikönyvében adóellenôrök számára fogalmazott me ajánlásokat. ${ }^{6}$ Majd kifejtette, hogy a Hivatal három fó területen találkozik korrupcióval. Egyrészt az ellenốrzések során feltárt esetek, korrupciós ügyletek kapcsán, másrészt adóhivatali munkatársat érintően, harmadrészt a Hivatal nevével történő visszaélések során. A belsố, hivatali korrupció megelőzése érdekében több terïlehivatali korrupció megolózése érdekében tỏbb területen folytatnak megelôzó, feltáró tevékenységet. Ezek közé tartoznak a belső vizsgálatok, a szuperrevíziók ( azok szerepének növelése ${ }^{\gamma}$ ), a szigorú belső biztonsági, megelózési tevékenységek, vizsgálati és kockáza felmérések, teamellenôrzesek, belsó vagyonnyilatkozatok $^{8}$, illetve egy új Etikai Kódex érvénybe léptetése. E mellett a Hivatal terve, hogy a feltárt ügyletek esetén a büntetés magánszemélyt-magánvagyont is érintse (SZJA)

Miklós Gábor, a PSZÁF Felügyeleti Tanácsána tagja közölte, hogy a PSZAF 2000 óta, mint integrá pénzügyi felügyelet múködik, összesen mintegy 2000 intézményt, és több mint 150.000 magánszemélyt felirgyel. Azonban komoly hínyosságnak tekintetó, hogy bár a létrehoze hogy bár a lćtrehozását elrendelố törvenyben "10 "áttétekorrupció szó sem szerepel sem a PSZÁF-törvényben, sem aZ SZMSZ-ben, senmilyen dokumentumban". $S$ nem mentség, hogy a nemzetközi szervezetek dokumentumaiban is csupán a korrupcióval összefügg fogalmak jelennek meg ${ }^{11}$ - a korrupció nincs nevén nevezve. Ennél is súlyosabb gond, hogy „őszintén szólv még sose vettük igazán szamba, nem rendszereztük az hogy a pénzügyi intézményeknél vagy magánál a Felügyeletnél milyen korrupciós lehetőségek vannak, pedig alighanem bőven vannak”. Minderre valószínúle égetó szükség volna, hiszen a felügyelt intézményekre a magas jövedelmezóség, a jelentôs beruháźśck a jellemzőek, s ezek bőven adnak teret a korrupció különböző formáinak.

A PSZÁF ezzel együtt több területen is igyekszik korrupció, illetve annak különböző formái ellen fellépni. Feladatából fakadóan a normál napi munka sorá vizsgálatokat folytat, ellátja piacfelügyeleti szerepe ajánlásokat tesz ${ }^{12}$, illetve panaszkezelési feladatokat is végez (korrupcióra utaló panasz egyébként csak kivételesen érkezik). Ezen túlmenően 2006-ban létrehozták a Pénzügyi Visszaélések Elleni Fơosztályt, amely elsốsorban pénzmosással, terrorizmussal, bankbiztonságg foglalkozik, így a korrupció is e Főosztály érdekszférá- jába tartozik. A belső ügyek kezeléséról Etikai Kódexszel is rendelkezik, amely azonban „felülvizsgálatra erett. A PSZAF lehetséges Korrupció ellenes tevékenységi köre négy pontban foglalható össze. Egyrészt nemrégen jóváhagyásra benyújtottak egy átdolgozott SZMSZ-t, ebben már szerepel (először a PSZÁF történetében!) a „korrupciô" szó. E mellett egy körkérdést küldtek az európai felügyeleteknek, melyben szakmai gyakorlatukról kértek tájékoztatást. A korrupció elleni stratégia kidolgozását még nem kezdték el, egyelőre a módszertan is várat magára. Csakúgy, mint a tervbe vett , whistleblowing" rendszer kidolgoźn tervve a pénzïgyi intér genyek szövetségeivel valo közös ve a pénzügyi intézmények

Dr. Bod Péter Ákos, a Budapesti Corvinus Egyem egyetemi tanára kiindulásként emlékeztetett rá hogy az érzékelt korrupció és az egy fốre jutó GDP közt erôs korreláció van, ám ebbốl nem következik semmifajta oksági összefüggés. „Csak azt lehet körülbelül tudni az irodalom alapján, hogy a szegényebb országok általában korruptabbak", ami a túl nagy állam, és az ehhez esetlegesen társuló magasabb korrupciós szint közti összefüggést sem magyarázza - a szakirodalom legalább is nem mutat ki erôs kapcsolatot az állam terjedelme, nagýága ́́s a korrupció elterjedté ge kät Ú lay la ge közt. Ungy látta azonban, hogy a kisebb állam felé haladás (privatizáció) nagyobb korrupcióval jár, mint a stabil centralizációs ráta. A korrekciós lehetôségek közt pedig a hivataloknak (pl. KSH) a kormánytól független múködtetését, a „civil service” visszaállítását valamint a kulturális tényezóket ítélte a leginkább ígéreteseknek.

Dr. Dávid Ibolya, volt igazságügyi miniszter, az MDF elnoke a politikai korrupció tárgykörét érintve meglehetősen (ön-)kritikus hangot ütött meg. Hangsúlyozta: „Magyarországon a korrupciós gondokért elsó helyen a döntéshozóknak van komoly felelóssége", s , a döntéshozók nem tesznek meg mindent azért, hogy változás ́lljon eló a jelon tozás áljon eló a jelenlegi helyzetben". A kormányzat korrupció elleni lépéseit bírálva kiemelte: „2001-ben fogadtuk el az egyetlen olyan átfogó korrupcióellenes programot, amelyik nem maradt csak program, hanem a végrehajtása is elindult. ...Az a két lépés, ami az elmúlt időszakban korrupció ellen történt, édes kevés volt!” Az Antikorrupciós Koordinációs Testület például „,sendben múködik”, eredményeiról nincs hír (de a nyolcmilliós támogatás egy ilyen testület múködtetésére nem is tekinthető elégnek). Úgy vélte: a korrupció elleni küzdelem élén a Parlamentnek kellene állnia, ám az Országgyuulésnek - mindaddig, amíg ezt nem sa- ját magánál kezdi - nincs morális alapja ahhoz, hogy mások életét mélyrehatóan módosító korrupció elleni döntéseket hozzon". De az is siralmas, hogy az Országgyúlés „„évről évre átlépi az Állami Számvevőszék jelentéseit, nem tesz eleget annak a kérésnek, amit intézmény ezen egyedüli ellenőrző testülete évról évre megfogalmaz".

Berényi Lajos, a Közbeszerzések Tanácsának elnöke elsóként arra emlékeztetett, hogy a közbeszerzésról szóló törvény jelenleg módosítás alatt áll, s a zesrớl szóló tơrvény jelenleg módositás alatt âll, s a cél az, hogy áttekinthetőbb, tisztább legyen a közbe szerzés szabályozása, nagyobb legyen a nyilvánosság. Majd arra a gondra mutatott rá, hogy bár a közbeszer-
zési piac mérete ma évi 1500-2000 milliárd forint, ám zési piac mérete ma évi 1500-200 milliárd forint, á az utóbbi időben az Országgyúlésre, de egyéb más döntéshozó szervekre is nagy nyomás nehezedik annak érdekében, hogy különbözố beszerzési tevékenységeket kivonjanak a közbeszerzési törvény hatálya alól..$^{13}$ Súlyosbítja a problémát, hogy a kapcsolódó törvények hatásainak vizsgálata nem készül el. Az utóbbi években például a tárgyalásos eljárások aránya nagymértékben növekedett, míg a nyílt eljárásoké csökkent, ami a nyilvánosság sérülésével jár. ${ }^{14}$ Sốt, egyre több a „hirdetmény nélküli tároyalásos eljrás"15, amely a nyilvánosság ${ }^{16}$ abszolút kizárását eled rás , amely a nyilv'sesto elyamatba beépített fé az, hogy a másolato el kell küldeni a Közbeszerzés Döntóbizottság elnökének, akinek joga van jogorvoslati eljáást kezdeményezni.17 Pedig a közbeszerzés
„fószereplói”, a legnagyobb ajánlatkérók, pályázat felhívást kiírók - a központi költségvetés szervei, minisztériumok, önkormányzatok és a többségébe állami tulajdonú szolgáltató vállalatok - és a döntése meghozói nagyon sok esetben nyomon követhetőek lennének, ami kulcsfontosságú tényezô lehetne az elszámoltatás kapcsán.

Dr. Alexa Noémi, a Transparency International Magyarország igazgatója kiindulásként arra mutatott rấ hogy a TI Korrupció Érź́kelési Indexe (az ún. CPI)

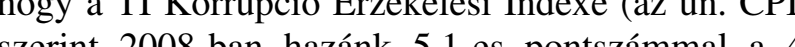
szent a helyen all, azaz a tavalyi 5,3-as ponját rontva nyo hellyel visszacsúszott. Ez azêt aggaszo, nert - bár az utóbbi tíz évben a CPI pontszánunk nem mozdult jelentôsen az 5-ös pontêrtéktôl, tehát ,a minket értekelô ország elemzók úgy látják, hogy nem történt e mozdulás a hazai korrupciós helyzetben”- Közép-Kelet-Európa ország-értékei folyamatosan javulnak, így a régió országai behozhatják Magyarországot, s eddigi téren viszonylag kedvező regionális pozíciónk akár is veszhet.

\section{VEZETÉSTUDOMÁNY}

A korrupció szempontjából leginkább problematius hazai területek a megoldatlan párt- és kampányfinanszirozás, az alláha me ke gyenge jogalkalmazás és az enyhe szankciók rendszee, a korrupció társadalmi elfogadottsága, a civil szféra altalános gyengesége és a korrupció megfékezésével kapcsolatos politikai akarat hiánya. Mivel például a közbeszerzések nem átláthatóak és a tárgykörben a döntések nem számon kérhetőek, a rendszeres korrupció zeket az eljárásokat a TI becslése szerint $15-25 \%$-ka rágítja. További probléma hogy az ombudsmannak, letve az ÁSZ-nek az ajón figyelmen kívïl maradnak, hogy a köz-és politika

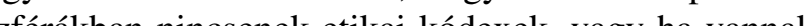
is, elor a lkat nem tarjak be, hogy a ny ha wannak ek nem rendelkeznek elég eszközzel, kapacitśs és elkésziültség el a sź eszónzzel, kapacitással és a civil szeggel a szánon kéréshez, illetve a média és a civil szervezetek ellenórzó kapacitása korlátozott, solszor politikailag befolyásolt. Ezért a TI ajánlásoka goazott meg a politikai pártok finanszírozásának sokkal szigorúbb szabályozására, a közbeszerzési jogzabályok egyszerüsítésére és hatékonyabb érvényesítesere, a bünüldözési szervek szerepének és kapacitasának erősítésére, a közérdekú bejelentók hatékony védelmére. Ezek megoldásán túl a TI saját kidolgozásû

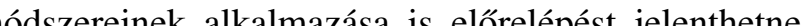
Segíthetné például a megtisztulási folyamatot az át-

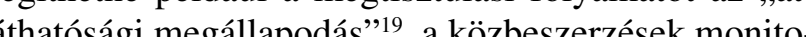

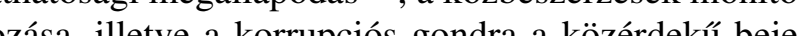
entés lehetőségét ${ }^{20}$ is magában foglaló figyelmeztetô (whistleblower) rendszer kialakítása.

Dr. Mózs Elek vezérốrnagy, a Vám- és Pénzügyoôrogy a VPOP a pénzügyi-gazdasági bunncselekmenyek területén nyomozó hatóságként engedélyező, ellenôrzố és bünüldòzôi funkciót is ellát, igy mindhárom területen a korrupció érintettje lehet. Idézte James Shavert, a Vám Világszerveze ${ }^{21}$ egy prominens vezetójét, aki szeint ,kevés olyan közigazoatási szervezet van, ahol az

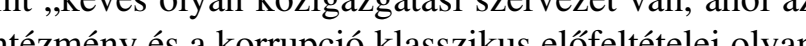
"đósen jelen vanak, min a vánnál". Ezétételei olyan éch a egyik, ha nem éppen a legszigorúbban és legsưurúbben ellenônórzés endszere és állomány biztonsági részlege is van - az

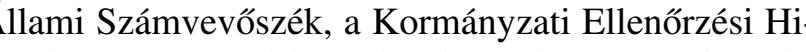
vatal, a Pénzügyminisztérium is rendszeresen vizsgál.

Ugyanakkor a VPOP korrupció elleni küzdelmét több tényező is nehezíti. Az EU-csatlakozást követően a legkülönbözốbb búnszervezetek számára lehetôvé vált, hogy Magyarországra is kiterjesszék tevékenységüket, gazdaságunkban is meghonosítsák a nemzetkö- 
zi búnözést és az ahhoz kapcsolódó korrupciót, ami a VPOP-tól is az új helyzethez való alkalmazkodást követel. Másrészt a VPOP berkein belül is számos, a ko rupciót növeló tényező van. Ez utóbbiak körébe soroható az erôs létszámleépítés és a nagyfokú fluktuáció, folyamatos reálbércsökkenés, az ellenőrző szervezetek létszámának csökkentése, valamint a szintén problematikus, beosztásfüggő „C" típusú nemzetbiztonsági ellenőrzés. E tényezók miatt különösen fontosak megelózési erőfeszítések, melyekre a szervezet nagy hangsúlyt fektet. Korrupció elleni eszköztáruk legjelentốsebb elemei az oktatás, egyes jogi eszközök, így

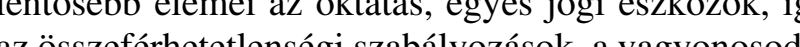
zés és felderítés.

Dr. Lomnici Zoltán tanácselnök, a Legfelsóbb Bíróság volt elnöke bevezetôként elsősorban az Európ Tanács felhívását és javaslatát ismertette. A felhívăs szerint meg kell akadályozni, hogy a sajtó nyomást gyakorolhasson a bíróságokra, mert ez komolyan befolyásolhatja az egyes ügyek lefolyását, a tárgyalások kimenetelét. ${ }^{22} \mathrm{~A}$ javaslat szerint pedig úgy kell meghatározni a bírák illetményét, hogy minél inkább csökkentse a korrupció lehetőségét. E törekvésnek hazánkban komoly gátló tényezójie, hogy ez lesz id a zánkban komoly gátó tényezôje, hogy ez lesz idén

A továbiakban a tácselnk kienelte, A tovabiakban a tanácselnôk kiemelte, hogy a korrupció megelôzésének fontos eszkōze a bír koorültekintó „toborzása" és megfeleló kiválasztása. Hazánkban e területen szintén van tennivaló. A magyar gyakorlatban ugyanis ahhoz, hogy valaki bíróv válhasson, jelöltként központi felvételi vizsgát ke tennie a Magyar Bíróképzó Akadémián ${ }^{23}$, s az adot megyei bíróság elnöke a sikeres vizsgát tett jelöltek közül választhat. $\mathrm{E}$ döntés annak szubjektivitása $\mathrm{m}$ att vitatható ugyan, ám jelentôs előrelépés a korábbi gyakorlathoz képest, , amikor minden döntési jog egy kézben összpontosult". Mindezeken túl fontos az öszszeférhetetlenség szabályozása, a hiteles vagyonnyilatkozat tétel, a szignálás rendje, a bírók kizáránijogi szab́́lyozása és a bíró elmozdíthatatlansága is.

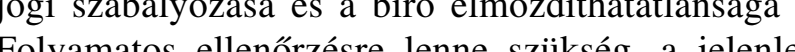
Folyamatos ellenórzésre lenne szúkség, a jelenlegi szabályozás szerint ugyanis egy bizonyos életkor utan az ellenôrzés megszann. Am minden fent említet jogi eszköz hatástalan, ha nincs a bíronak alapvetô erkölcsi tartása, amelyet szintén már a kiválasztás sor ellenớrizni kellene. Végül sikerként számolt be arró hogy 2008-ban elindult egy korrupcióellenes MBA kurzus, melyen a hallgatók egyrészt a bíró(ság)i korrupció módszereit, másrészt konkrét eseteket ismerhetnek meg.
Járai Zsigmond, az MNB korábbi elnöke szerint megnövekvő korrupció számos csatornán keresztïl rontja egy ország versenyképességét. Ez, bár direkt kapcsolat nem mutatható ki a gazdaság lassulásával, mégis egyik oka annak, hogy Magyarországon egyre lassabb es egyre rosszabb a gazdasági növekedés". Ennek következtében megnőnek az állami kiadások ${ }^{25}$, mérhetốen drágulnak az állami beruházások és múködtetési kiadások, aminek hatására nagyobbak lesznek az adóelvonások. A bonyolult adórendszer a feketegazdaságot is erôsíiti, s az államigazgatásban az alkalmazottak számát is növeli, ami miatt az iránýtás könnyen széteshét. A vállakloźi szekto pedig a sagy ado (a) háa ók elbizonytalanodását eredményezi, số, elriasztja a hazaies kulfoldibefektethet, valum kontraszelekciós mechanizmust válthat ki, amely torzítja a versenyt, azokat részesíti elonnyben, akik ilyen körülmények közt „ügyeskedve” tudnak boldogulni. A gondok fó okai az átláthatóság hiánya, az állami- és pártbürokrácia öszszekeveredése, s a felszínre került visszaélések „elhalása", a felelósségre vonás elmaradása. A mindezek elleni küzdelem fó eszköze a „cselekvés”, a határozott korrupció elleni erófeszítés lehetne, amelyet felülról kellene elindítani, s kezdô lépéseként a minden téren elkerülhetetlen egyszerúsítés javasolható.

Németh István, az AkzoNobel ${ }^{26}$ vezérigazgatója azt emelte ki, hogy az AkzoNobel a HEBC (Magyar Európai Üzleti Tanács) tagjaként a korrupció minden formáját elutasítja. Széles körú korrupció elleni gyakorlatot alakítottak ki abból kiindulva, hogy az értékek és alapelvek kommunikálása és a vezetôi példamutatás elengedhetetlen. ${ }^{27}$ Egységes, minden országra kiterjedô Magatartási Kódex (Code of Conduct) szerint múködnek, rendszeres tréningeket tartanak. Betartják az üzleti integritás (lényegében: átláthatóság) elvét, támogatják a tiszta versenyt és e tárgyban rendszeresen képzik kereskedőiket, könyvelésük teljes körú és pontos, külsó auditorokat alkalmaznak, akik csak azt vizsgálják, hol vann a cégnek konupcios gyenge ponjai stb. Töre véseike ceror kelle A segisegn az lehene az apelve kellene. A segitségnek az lehetne az alapelve, hogy "minel szulajekínebb egy döntés, a dôntéshozók annál szubjektívebbek lehetnek, ami a korrupció melegágyát teremti meg". Ezért fontos lenne a hazai bürokrácia egyszerúsítése, mert egy bonyolult rendszer csak gerjeszteni képes a korrupciót, visszafogni nem. Szükséges volna azonban a KKV-ket érintố terhek csökkentése is, mert jelenleg „,magasak az élốmunka terhek, ezért a kicsik nem tudnak versenyezni a nagy vállalatokkal", és mivel e szektor alapvetően is forráshiányos, a ma- gas elvonás csak a fekete foglalkoztatást gerjeszti. De a társadalmi etika változása sem nélkülözhetố, ugyanis amíg a lakosságnak „nem érdeke a számlák gyújtése, addig csak nagyon lassan javulhat a helyzet". Az ép tőipar különösen széles körben tekinthetó a korrupció melegágyának..$^{28}$

Dr. Papanek Gábor elnök szerint a korrupció közvetlen éves kára Magyarországon körülbelül évi 1000 milliárd forint, ${ }^{29}$ ám a közvetett károk még ennél is jelentốsebbek. A visszaélések rontják a versenyképesse get, versenykorlátozó hatáśak, valamint nagy néték get, versenykoralozó hatásúa, valamint nagymérték De torábi kösetkezményeik a hibás De további következményeik a hibás forrásallokáció,
a társadalom értéktudat rombolása, ${ }^{30}$ illetve, amiról ritkábban esik szó - már-már horribilis a teljesítményvisszatartó következmények miatt elmaradt haszo mértéke is. Ezeken kívül speciális hatások is fellépnek: a nagy összegú beruházások nagyobb korrupcós lehető́ségei miatt visszaszorulnak a kis költség fenntartási tevékenységek, torzulnak a pályaválasztá döntések ${ }^{31}$ stb. A visszaélések elleni küzdelem célszerú eszközei komplexek: egyrészt nélkülözhetetlen a köz-pénzügyek átláthatósága, nyilvánossága, valamin a gyakran elfelejtett elszámoltathatósága ${ }^{32}$. Másrészt fontosak a társ etsziḱt alaḱtó intéz. Másrés

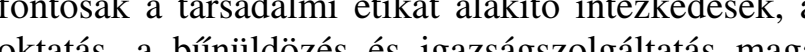
oktatás, a butaltatás mag nzígvonala. Mindezek hazai érvennyesítese érdekében tipikusan elterjedt struccpolitika helyett szembe ke nézni a problémákkal, reális diagnózist kell felállítan Fontos, hogy „Ne törődjünk bele!” - nem igaz ugyanis, hogy a korrupció (ilyen magas szintje) elkerülhetelen. A megoldás érdekében „Tárjuk fel a korrupció ellenérdekeltjeit!", lássuk be, hogy a visszaélések ellen küzdelemben a társadalom többségére számíthatunk. Ezt követốn a terápia már egyszerú, azt kell elvárnunk, amit Nelson admirális is várt: „Mindenki tegye a kötelességét!".

Dr. Sinku Pál, a Legfốbb Ügyészség Kiemelt Ü oyek Fốosztályának fóosztályvezetố ügyésze a korUgyek rupciót olyan búvópataknak jellemezte, ,amelyet mindenki lát, csak éppen nem tudjuk megfogni”. Mint mondta, az Ügyészség igyekszik a tudomására jutot eseteket "valamilyen modon feltárni, és valahogy bíróság elé vinni." Ennek ellenére az elmúlt tíz évbe az ismertté vált vesztegetéses ügyek átlagos száma 697 volt, ez az évenként regisztrált búncselekményeknek egy, azaz egy ezreléke! ${ }^{33}$ Az Ügyészség tapasztalat szerint a korrupciót leginkább kiváltó tényezôk a társadalmi szereplók felkészületlensége, a folyamato átláthatatlansága, a kiterjedt bürokrácia, a felelősök sztázatlansága, a közszférában foglalkoztatottak kelló nyagi megbecsültségének hiánya, a rosszul múködô llenôrzési rendszerek, a szabályozó rendszerek tökéletlensége, az államigazgatásban a túlzott diszkrecionális jogkör, valamint a lelepleződés csekély veszélye. Megfigyelésük szerint „,a korrupciós búnözésnek fontos jellegzetessége a gyors alkalmazkodási készség a társadalmi-gazdasági élet új lehetôségeinek kihasználására, valamint a láncreakciószerû́ terjedés, különösen olyan helyzetekben, amikor a döntéshozó saját elhatározásától, vagy méregéćétól függ anak elintézési módja." A kor ción A kompciós kapcsolato jellemzóen külső személy kezdeményezi. A legtipikusabb elkövetési magatartás

Dr. Kovács Árpád, az Állami Számvevôszék eloke szerint a korrupció „,gerjesztésében” az adott ország költségvetésének kialakítása a meghatározó, de a fejlesztesi források ingadozása is pozitívan korrelál a korrupcióval. ${ }^{34} \mathrm{Az}$ âllami élet, a makrogazdaság menedzselése területén azonban Magyarországon nincsenek meg azok a szignifikáns lépések, nincs meg az a fajta kiegyensúlyozott, előrelátó harmónia, amelyek a azdasági folyamatok kiegyensúlyozott múköóéséhez szïkségesek Rendkívïli korrupciós lehetóség az is, ha a magyar ́llom érvén

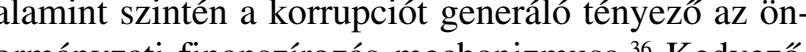
(a) Kedvezó, hogy „az Allami Szâmvevôszék határozottan fellépett zz ellen, hogy a közbeszerzési szabályozásban olyan fellazító értelmú szabályozást alakítsunk ki, amely ágymond egyszerúsítené a közbeszerzési eljárásokat." Javasolható továbbá a hosszú távú gondolkodás, az integritás alapú szemlélet meghonosítása, az intézményi és jogszabályi stabilitás megteremtése, a korrupciós térképek készítésére, végül a különböző intézmények közti, illetve az intézkedések és költségvetési kapcsolataik közti harmóniák megteremtése.

Végezetül zárszavában Szarvas István, a Szervezőbottság társelnöke arra mutatott rá, hogy a konferencián több elóadó kapott szót, mint a korábbi, 2006-os endezvényen. Egyaránt örvendetes a 2006 óta ismét megalakult Transparency International Magyarország képviselójének részvétele, az igazságügyi elóadók növekvố száma, a korrupció ellen szakterületén küzdó hivatalvezetók beszámolóinak bővïlố köre és az, hogy egy nagyvállalati előadó is kifejthette nézeteit. Mindez segítheti egy, a korrupció ellen küzdő, vagy ellene küzdeni akaró vezetố tisztségviselók közti konzultációs fórum és cselekvési közösség megalakítását. 


\section{Lábjegyzet}

Ezek: Igazságügyi és Rendészeti Minisztérium, Miniszterelnöl Hivatal, Nemzeti Fejlesztési és Gazdasági Minisztérium, Pénzügy Minisztérium, Önkormányzati Minisztérium, Egészségügyi

Ezek az Állami Számvevószzék, a Gazdasági Versenyhivatal, a Kozzbeszerzések Tanácsa, a Legfóbb Ugyészség, az Országos A Transparency International, a Pénzügykutató Ztrt., a Társasá a Szabadságjogokért jogvédô szervezet, az Országos Kriminolôgiai Intézet, valamint Farkas Ákos és Hack Péter, mint a terül elismert szakemberei.

Erre többek közt az ÁSZ és a holland számvevőszék közö "Twinning Light" projektje a példa

tre pelda. „Ápilis 1-en hatályba lépett a közpénzekból nyújto melynek értelmében nem pályázh 2007. évi CLXXXI. Törvény,

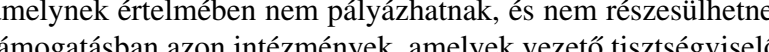
je a döntés-elókészítésból és a döntésból kizárt személy, illetve annak közeli hozzátartozója."

'A mû́ pontos címe: OECD-Kézikönyv a Vesztegetéśó́l Adóellenőröknek, elérhetősség: http://www.oecd.org/dataoecd/3/ 11/39949442.pdf

Jźráselulellenốrzés lehetớsége - azon esetekben alkalmazott elJáras, ha ugy tún, a avizorok nem negfeleló szakmaisagg vonatkozó szervezeti egységének létszámát, s ez által a korább évekhez képest megsokszorozta az így végzett ellenőrzéseket. Ezt idén 8200 fónél végezték el, ez a korábbi létszám 4,5szerese.

Az Etikai Kódex az alábbi címen érhetố el: http://www.apeh.hu data/cms52407/likikai_kodex.pd

A Felügyelet létrehozását elrendeló törvény ,úgy fogalmazta meg a celját, hogy a pénzügyi piacok zavartalan és eredményes verkódése, a piaci viszonyok áláhatósága, a tisztességes piaci

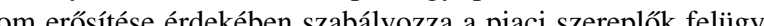
letét."

"Úgy, mint operációs kockázatok, belső kontrollok, pénzügyi viszszaélések, felelőss vállalatirányítás, csalások, manipuláció stb. A PSZÁF ajánlásai: http://www.pszaf.hu/engine aspx?page =pszafhu_ajanlirelvutmu

Ezek nagyságrendje több százmilliárd forint, ide tartoznak példáu a védelmi beszerzésés beszerzései, a kórház értékesítések stb.

Tént en történik, nem nyilvános.

Ekkor az eljást a Közbeszerzési Értesítóben sem kell megje(ntetni, ez esetben ugyanis a palyázati felhívás kiiroja kér fol cégeket, hogy azok tegyenek ajánlatot.

celenleg is vita folyik arról, hogy a közbeszerzési szerződése tejes egészében nyilvanosak legyenek-e, vagy sem. A mai szztitok fogalma, kritériumai nincsenek a jogszabályokban pontosan szabályozva

A kozbeszerzés központi intézményrendszerének tulajdonkép eldöntése, ami persze nagyon jelentốsen képes a szabálytyalan gokat csökkenteni, hiszen évente 800-1000 jogorvoslati eljár múködik, és ebbốl mintegy 35\%-nál megállapítanak szabályta- lanságot, és a szabálytalanság megállapítása esetén lehetséges a pályázati eredmény megsemmisśtése, bírság kiszabása. Most a elveit át kell venni minden tagországnak, ennek egyik nagyon lényeges eleme lesz, hogy addig, amíg az elsớfokú jogorvoslati eljárás nem zárult le, ha jogorvoslat van, akkor szerzódést nem lehet aláíni. Tudniillik korábban, és jelenleg is, ha jogorvoslati eljárás folyt, közben a szerződést aláírták, s utólag már elég ne-

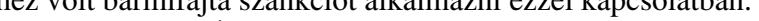
A TI Korrupció Érzékelési Indexe ,azt mutatja meg, hogy egy adott országot mennyire érzékelnek korruptnak befektetốk, üzletemberek, ország elemzók, tehát nem azt mutatja meg, hogy ruptnak."

Ez tulajdonképp egy önkéntesen megköthetổ szerződés ajánlatkéró és ajánlattevớ közt melyben rögzítésre kerïl például, hogy a felek tartózkodnak mindennemú korrupciótól, vagy, hogy a szerző́dések részletei az üzleti titkot képezó részeket kivéve nyilvánosak.

Olyan esetek, amikor az egyén érzékeli, és jelenti, hogy a hivatalnál, ahol dolgozik, olyan visszaélés történik, amely súlyosan

A Világszervezet honlapja: http://www.wcoomd.org/home. Az elóadó arra a hazai esetre hivatkozott, melyben egy „hírhedt ujjágíro" viselkedésével azt próbalta elérni, hogy a biró „beso-
kalljon”, és új bírát rendeljenek ki, ám végül nem sikerült elérnie célját, a tárgyalás lezárultával pedig súlyos ítélet szuiletett.

A Magyar Bíróképzó Akadémia honlapján a kiválasztásról is találhatóak bővebb információk: http://mba.birosag.hu/Engine.

Lomnici doktor LB elnökként többször javasolta, hogy ilyen szabályt nem célszerú bevezetni, mert ,nagyobb teret nyerhet a korrupcio". Véleménye szerint az ellenörzést folyamatossá kellene eléréséénez jogszzabályi változtatás lenne sziükséges.

${ }^{25}$ A korrupció fóké́pp az állami pénzek elosztásához kapcsolódik

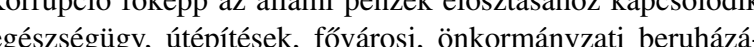
- egészséé

A holland tulajdonú AkzoNobel a világ vezetó festék és bevonatgyártoja. Honlapja: http://www.akzofaipar.hu

„Meggyózzódésem, hogy a legnagyobb korrupciókat a vállalatok akár a kicsi, akár a nagy vállalatok a vezetók tudtával hajtják végre,

„,Az építóipar kiemelten fertóöött korrupcióval. ....Ma a házak a re ... alakul a végeztek, akkor a projektcéget gyakorlatilag megsziunntetik, az alvállalkozókat nem fizetik ki, és innentól kezdve nagyon-nagyon nehéz óket ellenőrizn

hangsúlyozni, hogy magánzsebbe is nagyon kevés jut. A többségêt elpazarojajak! Ettunik a semmiben.... Olyan vesztesegek keletkeznek, amelyek a XXI. század menedzsmentelvei és (számítás-) technikai vívmányai mellett megmagyaráz-

„Egy idô után teljesen alapvetổ értékek, a tudás, a munka kérdóÉbdnek meg. És kialakul az a generáció, amely úgy gondolja, ,Mogy nem kell tanuln

rupt orszárban kevesen monnek mérnöknek esetleg közgazdásznak tanulnak a fiatalok."
${ }^{32}$ „A korrupció által lehetốvé tett 2002-es Enron-botrányt és az ez utáni világgazdasági nehézségeket követően az amerikaiak ige szigorú szabályokat írtak eló a vállalati pénzi̇gyi elszámolások számára és drasztikus szigorral büntetik ezek megszegését. A rendelkezések Magyarországon csaknem ismeretlenek, ped az ezekre épuilő Felelốs Vállalatirányítási Ajánlások a tốzsdei cégekre az egész világon, és Magyarországon is kötelezőek.

2007-ben mintegy 360 korrupciós büncselekmény vált ismertté. „Ha egy ország költségvetése különböző bizonytalan célok tartalmaz, egyik évben fölnövel bizonyos kiadási tételeket, bizo nyos evben bizonyos kiadási teteleleket lecsookkent, tehát fék-g negatív hatásai, amelyek korrupciót gerjesztenek. ...A költség -
vetésben lévoó fejlesztési források ingadozásainak van korrupció hatásmechanizmusa, és a korrupció elleni küzdelemnek makıo- gazdasági szinten a legkézenfekvóbb lehetốsége az, hogy egy kisźn thó gazdaságol es egy liszan

a vállalkozókat elônnyhö̀zsíti a kötbér követeléseit, így ket a tételeket, és Uram bocsá', az elmaradó kötbért meg is lehet felezni."

„A pályázati rendszerek késleltetése, a lassú elbíŕálás! Maradjunk ennél a tételnél. Nincs szinkronitás abban, hogy mikor érkeznek a különbözó pénzek. Gondoljanak arra, hogy az önkormányzatok mi, tudjanak ugrani. Eljutunk a klasszikus szituációnoz, amelyben teljesen mindegy, hogy mit árulnak a piacon, csak mindig legyen nálunk elégr rubel, hogy azt, ami éppen van, meg tudjuk venni. Az önkormányzati finanszírozásban nincs harmónia."

\section{AJÁNLÁS SZERZOINKNEK}

A Vezetéstudomány a Budapesti Corvinus Egyetem Corvinus School

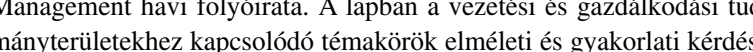
elemző és vizsgáló írások jelennek meg. A szerkeszztősegg (robert.becsky uni-corvinus.hu) elektronikus formában kéri az írásokat. A cikkeket elehronikus levélben vagy mágneslemezen (MS Word fájl formátumban) lehet a szerkesztősséghez eljuttatn.

A lap tudományos folyóirat, ezért szzövegközi forráshivatkozások és ezek jegyzeke nélküli iŕásokat nem jelentet meg. A Vezetéstudományban meggyelembevételét kérjük:

A cikkek szokásos terjedelme a hivatkozásokkal, ábrákkal és tábl

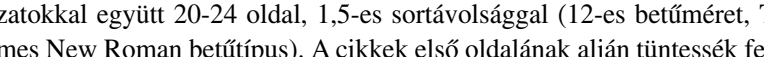
szerző foglalkozását, munkahelyét és beosztáśát, elektronikus leveleześ címét, a tanulmány elkészitésével kapcsolatos információkat és az esett ges köszönetnyilvánitásokat.

A kézirathoz csatolandó egy magyar nyelvứ és egy angol nyelvứ rövi témaköreit megnevezón kulcsszavak jegyzáke.

Kiemeléshez félkörýr śs dál jegyzźke. zeteket lehetốleg ne használjanak, amennyiben azok feltétlenül szükségosek, szzövegvégi jegyzetként adják meg.

A tablazazotoknak es abraknak legyen sorszáma és címe, valamint a kézirat végén, kuilön oldalakon, sorszámmal és címmel ellátva kér csatolni, helyüket a szövegben egyértelmúen jelölve (pl. .Kérem az táblázatot kb. itt elhelyezni!"')

A szövegkózi bibliográfiai hivatkozásokat zárójelben, a vezetékn és az évszám feltüntetésésével kériük jelölni: pl. (Veresss, 1999); szó szoPrahalad és Hamel, 1990:85). Amennyiben egy hivatkoztt szerzố több bibliográfiai tétele van ugyanazon évben, ezeket 1999a, 1999b stb. módon kell megkïlönböztetni.

A felhasznalt források cikk végén elhelyezett jegyzékét ábécérendb kérjük, a következő formában: Szerző (évszám): Cím, kiadás helye:
adó; illetve forrás.
1. példa (könyv): Porter, M.E. (1980): Competitive Strategy; New
York: The Free Press. 2. példa (folyóiratcikk): Prahalad, C.K. és G. Hamel (1990): The Core Competence of the

június, 79-91. o.

A formar kovetelmennyek fentiekben ervenyyesitett, unn. . Harvard" rend-

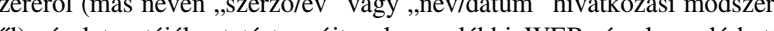
(bersok Az elektronikus forrásokra való hivatkozás aktuális probléma. Az Abret Library for Librarians egyik polca (www.itcompany.com/
fforetriever/inetcite.htm) kilenc helyet gyǘtiott osszze e témával kapcso-

Az angolszász orszáaokban több elterjedt formája van a bibliográ-

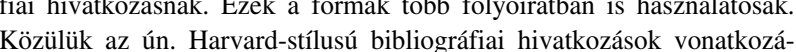
sában ad hasznos tanácsokat a Guide to Citing Internet Sources (www. bournemouth.ac.uk/service-depts/lis/LIS_Pub/harvardsystint.html). A Modern Language Association of America (MLA) - egyébkén sinteñ sok helyutt alkalmazott - hivatkozási stilusával kapcsolatban Az APA Publication Manual Crib Sheet (www.gasou.edu/psychweb/
psheet/apacrib.htm) az American Psychological Association (APA) idéesi stilusával foglalkozó forrásokat gyüjti csokorba. Havi folyoirat leveñ és a megjelenés atfutásis idejének csökkentése

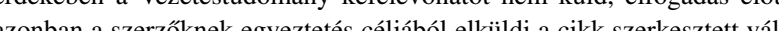
lozatát.

2006 januárjától az új lapszámok cikkeit es 2004-ig visszamenóleg az változatban is hozzáférhetốvé tesszük.

2009 januárjától a Vezetéstudományban publikált cikkek elérhetóék a ,WWw.securities.com" internetcimen talalhato strukturalt on-line inGormációs adatbázisban. Ha a szerzó nem járul hozzá cikkének eseti 